\title{
Participating Organization
}

National Cancer Institute

\section{Source}

National Cancer Institute. Participating Organization. NCI Thesaurus. Code C63411.

An organization associated with the Lead Organization and is active in the conduct of the research. 